\title{
THE JAVA TSUNAMI MODEL: USING HIGHLY-RESOLVED DATA TO MODEL THE PAST EVENT AND TO ESTIMATE THE FUTURE HAZARD
}

\author{
Widjo Kongko' and Torsten Schlurmann ${ }^{2}$
}

\begin{abstract}
This study is to validate the tsunami model with extensive field observation data gathered from the 2006 Java tsunami. In the relevant study area, where highly-resolved geometric data were recently made available and other related posttsunami field data have been collected, the tsunami maximum run-up onto land and its marigram have been simulated and evaluated. Several plausible tsunami sources are proposed to adequately mimic the 2006 Java tsunami by including the influence of low rigidity material in the accretionary prism as well as its single-multi fault source type's effect. Since it has a significant role on tsunami excitation, this parameter and other assumptions are then employed to study an estimated set of reasonable maximum magnitude earthquake-tsunami scenario and projected inundation areas for probable future tsunami on the South Java coastline. In a final step tentative technical mitigation measures are proposed and assessed to deal with adequate coastal protection issues by means of soft (greenbelt, etc.) and hard engineering (sand dunes, etc.) approaches. Their effectiveness in terms of reducing inundation area is assessed and general recommendations for coastal planning authorities are dealt with.
\end{abstract}

Keywords: tsunami model, highly resolved data, accretionary prism, single-multi segment faults, and technical mitigation measures

\section{INTRODUCTION}

\section{Past Events in Java}

Based on historical data, the number of earthquakes in Java's subduction zone occurred within the time period of 1977-2007 in bounding coordinates depicted in Figure 1 with magnitudes greater than Ms 5.0 and hypocenter shallower than $40 \mathrm{~km}$, is about 420 events. Among these candidates, two events of significant magnitude happened in 1994 and 2006. Each of them was followed by the sizeable tsunamis (ITDB/WLD 2007) causing damage and casualties on South Java coastline. According to USGS database for source parameters (USGS 2010), there are 20 events with magnitude above Mw

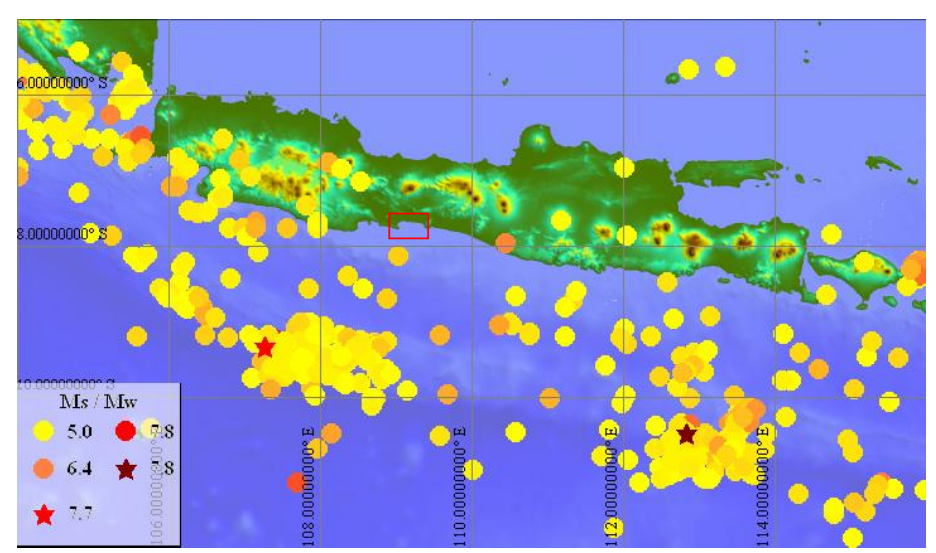

Figure 1. Earthquake (dots) \& subsequent tsunami (stars)

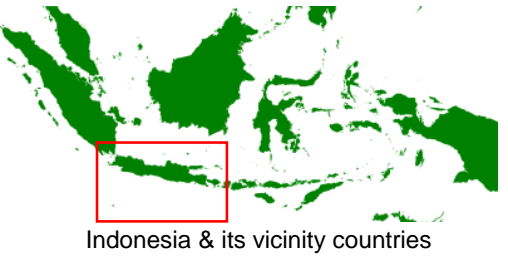

6.5 and depth less than $100 \mathrm{~km}$ within the time period of 1978 2008. Two earthquakes generated tsunamis occurred in depths less than $20 \mathrm{~km}$. Primary source parameters were almost identical, namely strike $\sim 278^{\circ}-297^{\circ}$, dip $\sim 10^{\circ}$, and slip $\sim 90^{\circ}$ respectively.

\section{Data and Tsunami Model Available}

Recently acquired topography data within the German-Indonesia Tsunami Warning System (GITEWS) have been assembled to set up a digital terrain model which clearly reveals the flat terrain slope in the respected studied area on the South coast of Java. In one of the pilot project areas, namely district of Cilacap (red box depicted in Figure 1) shown in Figure 2 remarkably illustrates the extraordinary low topography of the region. From the depicted 14 cross sections (black line) normal to

\footnotetext{
${ }^{1}$ PhD Student, UNU-EHS, Bonn Germany and PhD Researcher, Franzius Institute for Hydraulic, Waterways and Coastal Engineering, Leibniz University Hannover, Nienburger str.4, 30167 Hannover, Germany

${ }^{2}$ Managing Director \& Professor, Franzius Institute for Hydraulic, Waterways and Coastal Engineering, Leibniz University Hannover, Nienburger str.4, 30167 Hannover, Germany
} 
the shoreline indicate an average slope less than $\sim 1 \%$, and the maximum ground level approx. $9 \mathrm{~m}$ within average distance about $4 \mathrm{~km}$ inland (Intermap Federal Services 2007).

Furthermore, in this particular flat area more than 1.7 million people reside. This denotes a population density of 760 inhabitants per $\mathrm{km}^{2}$ and thus, characterizes a densely-urbanized coastal region with vast industrial production with approximately 80.000 labor jobs, including the cement industry, oil refinery plant, and steam power plant, which the latter is one of the vital backbones of the electrical supply in Java-Bali (DPPK-Cilacap 2007).

On July 17, 2006, a significant earthquake with magnitude Mw 7.8 occurred off the shores of the region and was followed by a tsunami attacking South Java's coastline, which killed more than 600 people. The coast of Cilacap also devastated by the

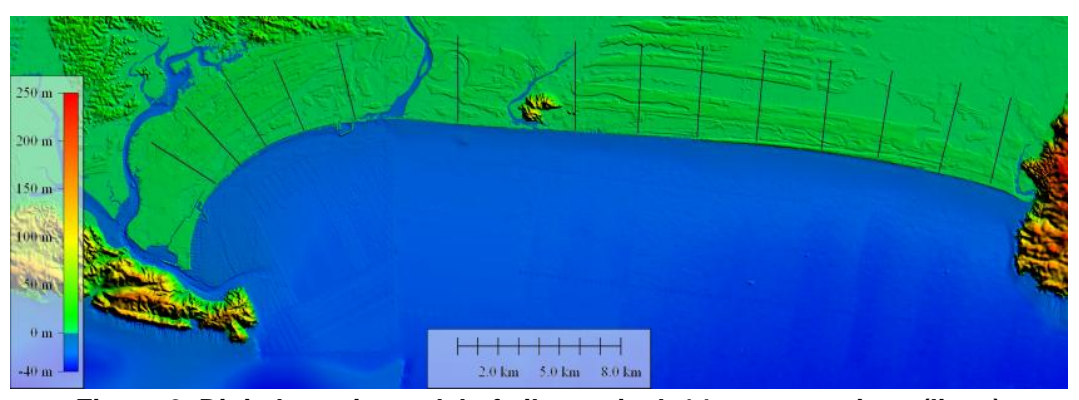

Figure 2. Digital terrain model of cilacap, incl. 14 cross sections (lines)

tsunami, which generated maximum run-up height reaching about $15-20 \mathrm{~m}$ in Permisan Nusakambangan Island, $20 \mathrm{~km}$ South-West of Cilacap (Fritz et al. 2007 and Lavigne et al. 2007), and about $6 \mathrm{~m}$ in the center Penyu Bay (Kongko et al. 2006). In this district, the disaster killed more than 150 people and affected hundreds of people (Z. H. Abidin \& Kato 2007).

Several numerical models have been proposed to effectively simulate the 2006 Java earthquake. DCRC Tohoku University Japan proposed four case models as available its result at Universities website, resulting in maximum run-up heights of approx. $3.5 \mathrm{~m}$, while the model introduced by CEADAM France only led to run-up heights of not more than $1.0 \mathrm{~m}$ as depicted by their published results provided on their website (CEA-France 2007). Another preliminary study conducted by the Tsunami Research Team, Bologna University, also proposes four cases of the fault parameter resulting in maximum run-up heights at the coastline of approximately $2 \mathrm{~m}$. Another model proposed by Hanifa et al. (2007), follows the approach of nested grids one and two minutes bathymetric resolution. These authors use low rigidity of $10 \mathrm{GPa}$ as previously suggested by Ammon et al. (2006). The latter attempt resembles the best fit model for 2006 Java tsunami leading maximum run-up heights about $6.3 \mathrm{~m}$ in the relevant area. All above proposed models, however, show strong discrepancies in comparison to the field observation of run-up heights along Java's coastline, which have been jointly collected by several researchers in the aftermath of the disaster.

Hitherto, the latter model proposed by Hanifa et al. (2007) is the only existing attempt which exposes similar run-up heights as it takes the larger slip due to low rigidity material in the excitation zone into account affected by so-defined accretionary prism as introduced by Ammon et al. (2006) and Kopp \& Kukowski (2003). However, due to the low resolution of the bathymetric and topographic data and limited number of field observation used, extensively model result comparison, i.e. tsunami run-up distribution along the coastline as well as its run-up onto land which is significant for model validation, has not been carried out yet.

In this context, the present paper thoroughly studies and attempts to validate the 2006 Java tsunami and in a further step assesses the extent of tentative future plausible tsunamis and the exposure of the coastal hinterland. First, we attempted to model the 2006 Java tsunami with several tsunami sources and comparing its run-up distribution with the field observation data, which had been collected in more than $400 \mathrm{~km}$ span of South Java coastline as conducted by International Tsunami Survey Team (ITST) as documented in several publications, such as Fritz et al. (2007), Lavigne et al. (2007), Takahashi et al. (2008), and Kongko et al. (2006). Furthermore, highly-resolved data of bathymetric and topographic has been made available within the framework of the current study so that evaluations and comparisons between model inundation and the 2006 Java tsunami's run-up onto land have been carried out. Moreover, numerical results are considered to analyze tsunami marigram measured at the tide gauge in Cilacap and tsunami evolution captured by video's witness. The components of source parameters that are most likely mimicking the extent of this event incorporated with the variation of additional assumptions, particularly in the determination of epicenters, magnitudes, and other tectonic properties in the relevant area, then, have been applied to model the future tsunami. For mitigation 
purposes and coastal protection strategies, we also examined the tentative technical counter measures in order to reduce tsunami impact, i.e. greenbelt and sand dunes.

\section{NEWLY GEOMETRIC AND OBSERVATION DATA}

\section{Geometric Data}

Within the framework of German-Indonesia Tsunami Early Warning Systems (GITEWS) project, a high resolution near-shore bathymetric survey equipped by a single-multi beam echo sounder has been recently conducted. The coverage survey area is approximately $70 \mathrm{~km}^{2}$ located in Penyu Bay off Cilacap city (Kongko \& Leschka 2009). In addition, bottom profiling of the main city channels and waterways in the area of depth less than $5 \mathrm{~m}$ has been carried out by a single-beam bathymetric survey using a small boat. Bathymetric data from the eastern part of the Penyu Bay has been provided by Coordinating Agency for Surveys and Mapping of Indonesia (BAKOSURTANAL 2007) by a single beam echo sounding with track acquisition grids ranging from 200-500 m. Thus, the entire Penyu Bay of the Cilacap district has been covered by using recent measurement data. In addition, offshore bathymetric data have been set up by using GEBCO 2008 data in 30 second arc resolution. All data from the various sources have been processed and assimilated to establish an exclusive digital bathymetry model.

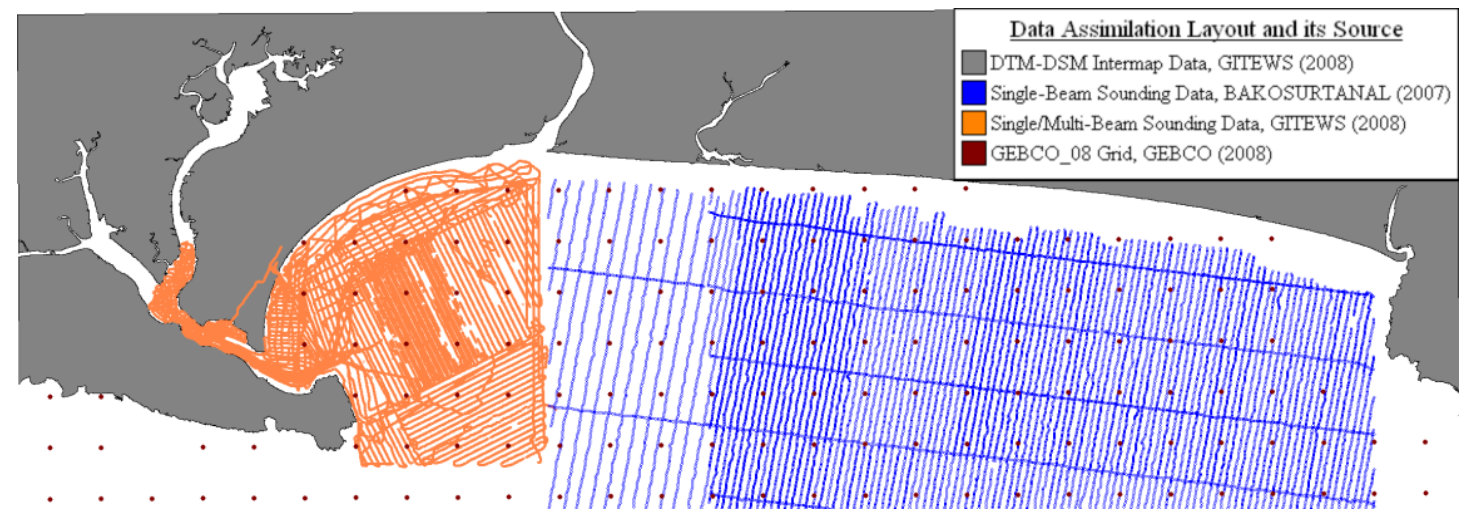

Figure 3. Layout of data assimilation \& its source of origin

In the framework of the project, topographic data using Intermap Technologies STAR-4 airborne interferometric SAR data have been collected. The data is about $5 \mathrm{~m}$ ground sampling distance basis in order to establish a most-sophisticated Digital Terrain Model (DTM) (Intermap Federal Services 2007). The layout of the data assimilation that have been collected and its source of origin is shown in Figure 3.

\section{Observation Data}

For model validation purposes, we initially collected data related with 2006 tsunami event as well as conducted the additional field survey in study area. The first one includes set of the tsunami run-up data along South Java coastline as observed by several international surveying teams, which were formed only a few days or weeks after the tsunami. The whole data set consists of about 390 points spanning more than $400 \mathrm{~km}$ coastline as collected by six teams, i.e. Tsuji et al, Fritz et al, Kongko et al, Lavigne et al, Fujima et al (PARI Japan team), and

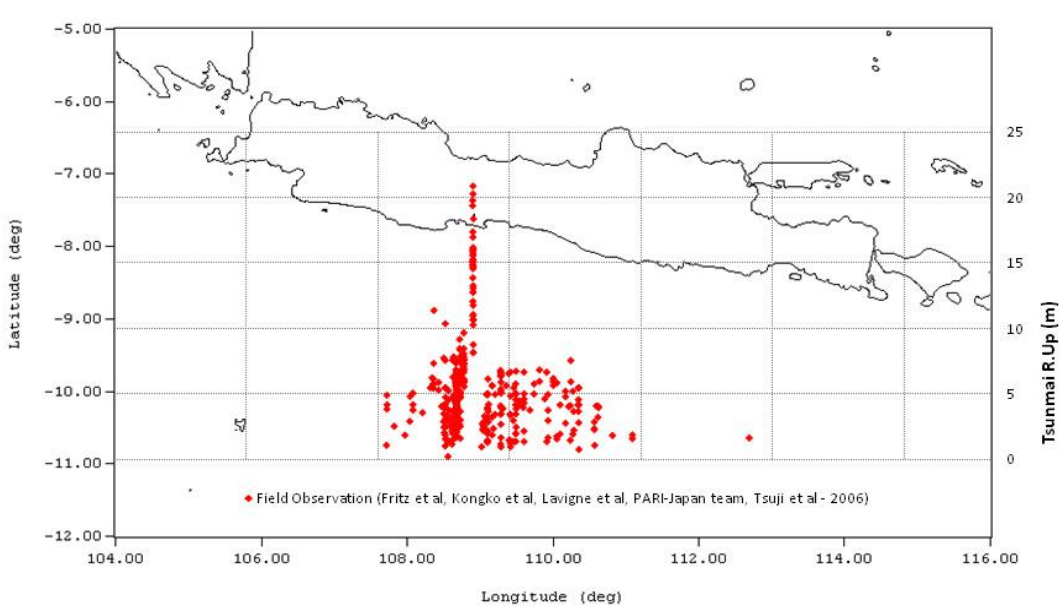

Figure 4. Tsunami run-up distribution in 2006 java tsunami 
Matsutomi et al, among them published the report in some articles (see the tsunami run-up heights distribution in Figure 4).

In reference to each measuring point of this unique dataset encloses: GPS position, tsunami run-up height, flow depth, ground level, beach slope, and further personal comments to indicate the assumed tsunami's trail on shore. However, for the validation reason of underlying tsunami run-up height distribution and in order to reduce uncertainties caused by topographic artifacts in surrounding area,

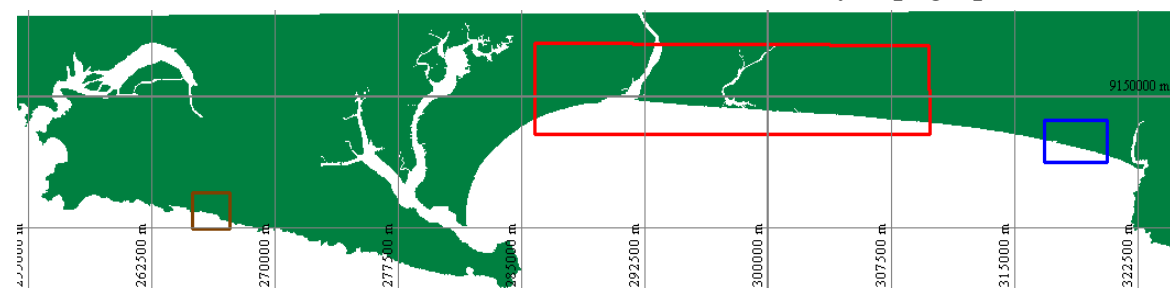

Figure 5. Lay-out of validation model; tile 1(brown), tile 2(red), tile 3(blue) only data with less than approx. $200 \mathrm{~m}$ distance from the coastline assuming the existence of typical beach profile and absent coastal vegetation have been considered. In addition, data without information about the inherent beach slope are excluded. This approach enabled a total of 110 pre-selected points of tsunami reference.

Furthermore, in the study area additional field surveys have been conducted. These surveys collected data such as coastal features surrounding the 39 points of maximum run-up and flow depth of the tsunami as conducted by previous tsunami survey teams (as the location depicted as brown box-tile 1 in Figure 5). Because of the fact such area is not covered by DTM data, we were also conducting the ground survey campaign by using total station and measured its level in more than 1200 points. Moreover, to attain the estimation of the maximum inundation points that had been reached by the tsunami in Penyu Bay of Cilacap, local people who experienced 2006 Java tsunami have been interviewed. Due to the time constraints, we only obtained 23 points of maximum run-up as bounding location shown in tile 2 (red box) and tile 3 (blue box) in Figure 5. In this area, we also obtained the information regarding the event, such as the earthquake's tremor, tsunami's estimation time arrival (ETA), the wave-counts, victims, etc.

\section{TSUNAMI MODEL OF 2006 JAVA EARTHQUAKE}

\section{Tsunami Sources}

For conducting the subsequent tsunami model of 2006 Java tsunami, we applied several tsunami sources as provided by previous researchers enumerated in Table 1 .

\begin{tabular}{|c|c|c|c|}
\hline \multicolumn{4}{|c|}{ Table 1. Source model of 2006 java tsunami-earthquake } \\
\hline No. & Fault Type & Authors/Sources & Description \\
\hline 1 & $\begin{array}{l}\text { Multi-faults } \\
\text { model }\end{array}$ & Fujii, Y. \& Satake, K. (2006) & $\begin{array}{l}\text { The tsunami source was derived from tsunami waveform } \\
\text { recorded at six tide gauges. }\end{array}$ \\
\hline 2 & $\begin{array}{l}\text { Multi-faults } \\
\text { model }\end{array}$ & Cheng-ji (2006) & $\begin{array}{l}\text { Fault rupture model was determined by the inversion of } \\
\text { teleseismic body waveform. }\end{array}$ \\
\hline 3 & $\begin{array}{l}\text { Multi-faults } \\
\text { model }\end{array}$ & $\begin{array}{l}\text { Ammon, C.; Kanamori, H.; } \\
\text { Lay, T. \& Velasco, A. (2006) }\end{array}$ & $\begin{array}{l}\text { The slip distribution from the finite fault inversion model } \\
\text { assuming low rigidity of } \mathrm{mu}=10 \mathrm{GPa} \text { and rupture speed of } \\
1.25 \mathrm{~km} / \mathrm{s} \text {. }\end{array}$ \\
\hline 4 & $\begin{array}{l}\text { Multi-fault } \\
\text { model }\end{array}$ & $\begin{array}{l}\text { RuptGen ver.1.1 - GITEWS } \\
(2010)\end{array}$ & $\begin{array}{l}\text { The single fault model was generated by using Ruptgen } \\
\text { model (ver.1.1) - GITEWS Project using rigidity normal of } \\
30 \text { GPa. }\end{array}$ \\
\hline 5 & $\begin{array}{l}\text { Multi-fault } \\
\text { model }\end{array}$ & $\begin{array}{l}\text { RuptGen ver.1.1 - GITEWS } \\
(2010)\end{array}$ & $\begin{array}{l}\text { The single fault model was generated by using Ruptgen } \\
\text { model (ver.1.1) - GITEWS Project using low rigidity of } 10 \\
\text { GPa. }\end{array}$ \\
\hline 6 & $\begin{array}{l}\text { Single-fault } \\
\text { model }\end{array}$ & Kongko, W. (2009) & $\begin{array}{l}\text { The single fault model which its dimension estimated by } \\
\text { empirical studies. The slip was calculated by using low } \\
\text { rigidity of mu=10 GPa. }\end{array}$ \\
\hline
\end{tabular}

Each source model provides an estimated magnitude and extent of underlying rupture dimension and its co-seismic slip. In order to obtain the sea-floor vertical displacement which is then being used as the initial sea surface height in the model, the deformation model developed by Mansinha \& Smylie (1971) is applied for fault model 1, 2, 3, and 6 and Okada (1985) for fault model 4 and 5. 


\begin{tabular}{|c|c|c|c|c|c|c|c|}
\hline \multirow{2}{*}{ No } & \multicolumn{2}{|c|}{$\begin{array}{l}\text { Epicenter of } \\
\text { sub-fault }\end{array}$} & \multirow{2}{*}{$\begin{array}{l}\text { Depth } \\
(\mathrm{km}) \\
\end{array}$} & \multirow{2}{*}{$\begin{array}{l}\text { Area } \\
\left(\mathrm{km}^{2}\right)\end{array}$} & \multirow{2}{*}{$\begin{array}{l}\text { Slip } \\
(\mathrm{m})\end{array}$} & \multirow{2}{*}{$\begin{array}{l}\mathrm{Mo}(\mathrm{Nm}) \\
\mathrm{mu}=30 \mathrm{GPa}\end{array}$} & \multirow[t]{2}{*}{$\mathrm{Mw}$} \\
\hline & $\begin{array}{c}\text { Lon } \\
\text { (deg) }\end{array}$ & $\begin{array}{c}\begin{array}{c}\text { Lat } \\
(\mathrm{deg})\end{array} \\
\end{array}$ & & & & & \\
\hline 1 & 107.12 & -9.211 & 3.0 & 2500 & 0.53 & 3.975E+19 & 7.0 \\
\hline 2 & 107.28 & -8.805 & 11.7 & 2500 & 0.15 & $1.125 \mathrm{E}+19$ & 6.6 \\
\hline 3 & 107.55 & -9.357 & 3.0 & 2500 & 0.51 & $3.825 \mathrm{E}+19$ & 7.0 \\
\hline 4 & 107.70 & -8.958 & 11.7 & 2500 & 0.00 & $0.000 \mathrm{E}+00$ & 0.0 \\
\hline 5 & 107.99 & -9.495 & 3.0 & 2500 & 1.38 & $1.035 \mathrm{E}+20$ & 7.3 \\
\hline 6 & 108.13 & -9.112 & 11.7 & 2500 & 0.79 & $5.925 \mathrm{E}+19$ & 7.1 \\
\hline 7 & 108.42 & -9.655 & 3.0 & 2500 & 1.43 & $1.073 \mathrm{E}+20$ & 7.3 \\
\hline 8 & 108.58 & -9.257 & 11.7 & 2500 & 0.00 & $0.000 \mathrm{E}+00$ & 0.0 \\
\hline 9 & 108.85 & -9.809 & 3.0 & 2500 & 2.47 & $1.853 \mathrm{E}+20$ & 7.4 \\
\hline 10 & 109.00 & -9.395 & 11.7 & 2500 & 2.12 & $1.590 \mathrm{E}+20$ & 7.4 \\
\hline & & & & & & $7.04 \mathrm{E}+20$ & 7.8 \\
\hline
\end{tabular}

Note: all sub-faults; strike, dip, and slip angle is $289^{\circ}, 10^{\circ}$, and $95^{\circ}$ respectively
The tsunami source of model 1 was derived by Fujii \& Satake (2006) by using inversion of the tsunami waveforms method which those were recorded at six tides gauges. The inherent tsunami source has $200 \mathrm{~km}$ length with the largest slip is $2.5 \mathrm{~m}$ for instantaneous rupture model. In order to estimate the extent of tsunami source and its slip distribution, they proposed 10 sub-faults with fault dimensions $50 \mathrm{~km}$ x $50 \mathrm{~km}$. By using this source model, the minimum and maximum sea floor vertical displacement is $-0.36 \mathrm{~m}$ and $1.03 \mathrm{~m}$ respectively. The source parameters are listed in Table 2.

Source model 2 is proposed by $\mathrm{Ji}$ (2007) and is based on the finite fault model which consists of 147 subfaults. The fault rupture model was determined by the inversion of teleseismic body waveform. Each rectangular fault has dimension of $15 \mathrm{~km}$ (strike direction) x $12 \mathrm{~km}$ (dip direction). This source model gives the minimum vertical displacement of $-0.22 \mathrm{~m}$ and maximum displacement is $0.46 \mathrm{~m}$.

Source model no 3 is derived from slip distribution developed by Ammon et al. (2006) using the finite fault inversion model assuming the ruptures is located in the so-called accretionary prism, which poses low rigidity material of $10 \mathrm{GPa}$. The slip distribution rectangular patches proposed by authors above are depicted in figure 6 . In the present study, we proposed the decomposition of the fault area of a total of 16 rectangular sub-faults (red boxes) to resemble slip distribution where each value was interpreted through the color scale and the total moment to be conserved as similar as original one. The parameters of this source model, i.e. epicenter, depth, fault dimension, and their moment is given in

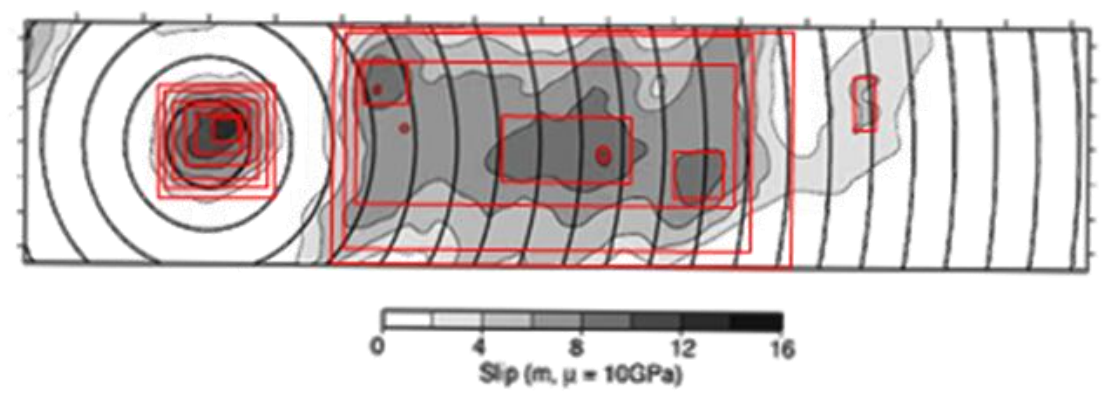

Figure 6. Slip distribution proposed by ammon et al (2006), and 16 sub-faults represent its slip proposed by kongko (2009)

Table 3. By using low rigidity material in the excitation zone, this source model yields a maximum slip of approximately $13.5 \mathrm{~m}$ and could generate vertical displacement up to $2.58 \mathrm{~m}$, while its minimum value is $-1.55 \mathrm{~m}$.

Source model 4 and 5 were obtained from rupture generation tool called RuptGen version 1.1, which was developed within the GITEWS project to support the establishment of the tsunami hazard map in Indonesia Babeyko (2007). This novel approach calculates the sea floor deformation caused by co-seismic slip at the Sunda trench region. RuptGen employs the concept of patches at the subduction plate interface, where the regular mesh of the rectangular patch (size $40 \mathrm{~km} \mathrm{x} 15 \mathrm{~km}$ ) represents the seismogenic in depth around $0-60 \mathrm{~km}$. In the present study, we apply the derived magnitude and epicenter as given in Table 4 with two conditions of the rigidity value, namely $30 \mathrm{GPa}$ and $10 \mathrm{GPa}$. By such parameters, the model produces 15 patches with the maximum and minimum sea floor vertical 
deformation of $1.03 \mathrm{~m}$ and $-0.42 \mathrm{~m}$ for normal rigidity as well as $3.09 \mathrm{~m}$ and $-1.25 \mathrm{~m}$ for low rigidity respectively.

\begin{tabular}{|c|c|c|c|c|c|c|c|c|c|c|c|c|c|c|c|}
\hline \multicolumn{7}{|c|}{ Finite-fault Inversion results of Slip distribution } & \multicolumn{9}{|c|}{ Proposed Patches' Parameters for Tsunami Model } \\
\hline \multirow{2}{*}{2} & \multirow{2}{*}{ 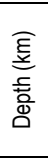 } & \multirow{2}{*}{ 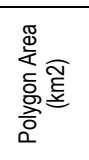 } & \multirow{2}{*}{$\begin{array}{l}\widehat{\underline{E}} \\
\frac{\varrho}{\bar{\omega}}\end{array}$} & \multicolumn{2}{|c|}{ Mo (mu=10 GPa) } & \multirow{2}{*}{ Mw } & \multicolumn{2}{|c|}{ Epicenter of sub-fault } & \multicolumn{2}{|c|}{ Fault Dimension } & \multirow{2}{*}{ 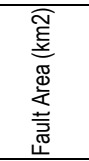 } & \multirow{2}{*}{$\begin{array}{l}\widehat{\underline{E}} \\
\stackrel{\underline{0}}{\omega}\end{array}$} & \multirow{2}{*}{ 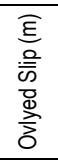 } & \multirow{2}{*}{ 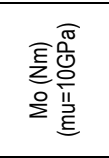 } & \multirow{2}{*}{ Mw } \\
\hline & & & & Overlaid & Residual & & Lon(deg) & Lat(deg) & $W(\mathrm{~km})$ & $\mathrm{L}(\mathrm{km})$ & & & & & \\
\hline 1 & 10 & 36.0 & 13.5 & $4.86 \mathrm{E}+18$ & $7.20 \mathrm{E}+17$ & 6.4 & 107.431 & -9.242 & 6.0 & 6.0 & 36.0 & 2.0 & 13.5 & $7.20 \mathrm{E}+17$ & 5.8 \\
\hline 2 & 10 & 168.0 & 11.5 & $1.93 \mathrm{E}+19$ & $3.36 \mathrm{E}+18$ & 6.8 & 107.398 & -9.239 & 13.0 & 13.0 & 169.0 & 2.0 & 11.5 & $3.38 \mathrm{E}+18$ & 6.3 \\
\hline 3 & 10 & 358.7 & 9.5 & $3.41 \mathrm{E}+19$ & $7.17 \mathrm{E}+18$ & 7.0 & 107.396 & -9.244 & 19.0 & 19.0 & 361.0 & 2.0 & 9.5 & $7.22 \mathrm{E}+18$ & 6.5 \\
\hline 4 & 10 & 584.0 & 7.5 & $4.38 \mathrm{E}+19$ & $1.17 E+19$ & 7.0 & 107.403 & -9.262 & 24.0 & 24.0 & 576.0 & 2.0 & 7.5 & $1.15 \mathrm{E}+19$ & 6.6 \\
\hline 5 & 10 & 817.0 & 5.5 & $4.49 \mathrm{E}+19$ & $1.63 E+19$ & 7.0 & 107.406 & -9.264 & 28.5 & 28.5 & 812.3 & 2.0 & 5.5 & $1.62 \mathrm{E}+19$ & 6.7 \\
\hline 6 & 10 & 1102.0 & 3.5 & $3.86 \mathrm{E}+19$ & $3.86 \mathrm{E}+19$ & 7.0 & 107.416 & -9.267 & 33.0 & 33.0 & 1089.0 & 3.5 & 3.5 & $3.81 \mathrm{E}+19$ & 7.0 \\
\hline 7 & 8 & 3.5 & 11.5 & $4.03 E+17$ & $7.00 \mathrm{E}+16$ & 5.7 & 107.845 & -9.276 & 1.9 & 1.9 & 3.6 & 2.0 & 11.5 & $7.22 \mathrm{E}+16$ & 5.2 \\
\hline 8 & 8 & 3.9 & 9.5 & $3.71 \mathrm{E}+17$ & $7.80 \mathrm{E}+16$ & 5.6 & 107.897 & -9.409 & 1.9 & 1.9 & 3.6 & 2.0 & 9.5 & $7.22 \mathrm{E}+16$ & 5.2 \\
\hline 9 & 8 & 17.3 & 11.5 & $1.99 \mathrm{E}+18$ & $3.46 \mathrm{E}+17$ & 6.1 & 108.394 & -9.633 & 4.1 & 4.1 & 16.8 & 2.0 & 11.5 & $3.36 \mathrm{E}+17$ & 5.6 \\
\hline 10 & 8 & 149.5 & 9.5 & $1.42 \mathrm{E}+19$ & $2.99 \mathrm{E}+18$ & 6.7 & 108.598 & -9.757 & 12.2 & 12.2 & 148.8 & 2.0 & 9.5 & $2.98 \mathrm{E}+18$ & 6.2 \\
\hline 11 & 8 & 789.0 & 9.5 & $7.50 \mathrm{E}+19$ & $1.58 \mathrm{E}+19$ & 7.2 & 108.294 & -9.542 & 17.5 & 45.0 & 787.5 & 2.0 & 9.5 & $1.58 \mathrm{E}+19$ & 6.7 \\
\hline 12 & 8 & 174.6 & 9.5 & $1.66 \mathrm{E}+19$ & $3.49 E+18$ & 6.7 & 108.240 & -9.572 & 13.0 & 13.0 & 169.0 & 2.0 & 9.5 & $3.38 \mathrm{E}+18$ & 6.3 \\
\hline 13 & 8 & 4645.0 & 7.5 & $3.48 \mathrm{E}+20$ & $9.29 \mathrm{E}+19$ & 7.6 & 108.221 & -9.587 & 45.0 & 100.0 & 4500.0 & 2.0 & 7.5 & $9.00 \mathrm{E}+19$ & 7.2 \\
\hline 14 & 8 & 7440.0 & 5.5 & $4.09 \mathrm{E}+20$ & $1.49 \mathrm{E}+20$ & 7.7 & 108.184 & -9.542 & 60.0 & 125.0 & 7500.0 & 2.0 & 5.5 & $1.50 \mathrm{E}+20$ & 7.4 \\
\hline 15 & 8 & 80.7 & 5.5 & $4.44 \mathrm{E}+18$ & $1.61 \mathrm{E}+18$ & 6.4 & 109.101 & -9.727 & 9.0 & 9.0 & 81.0 & 2.0 & 5.5 & $1.62 \mathrm{E}+18$ & 6.1 \\
\hline 16 & 8 & 10011.0 & 3.5 & $3.50 \mathrm{E}+20$ & $3.50 \mathrm{E}+20$ & 7.6 & 108.317 & -9.578 & 75.0 & 135.0 & 10125.0 & 3.5 & 3.5 & $3.54 \mathrm{E}+20$ & 7.6 \\
\hline & & & & & $6.94 \mathrm{E}+20$ & 7.8 & & & & & & & & $6.96 \mathrm{E}+20$ & 7.8 \\
\hline
\end{tabular}

Note: -all sub-faults, strike, dip, and slip angle is $289^{\circ}, 10^{\circ}$, and $95^{\circ}$ respectively

-conversion from Mo to Mw using Hanks \& Kanamori formula (1979)

The source parameters of model 6 are depicted in Table 4. By using low rigidity, we obtain a slip of $3.95 \mathrm{~m}$ which produces the maximum and minimum sea-floor deformation of $1.56 \mathrm{~m}$ and $-0.85 \mathrm{~m}$ respectively.

All source models mentioned above with several fault's types, rupture dimensions, and the assumptions of rigidity value that lead to difference slip, will produce various sea floor deformations. This will be as an initial sea surface height and input of the offshore boundary to trigger tsunami model explained in the next sections.

\begin{tabular}{|c|c|c|c|c|c|c|c|c|}
\hline \multicolumn{9}{|c|}{ Table 4. Source parameters of 2006 java tsunami proposed by kongko (2009) } \\
\hline \multirow{2}{*}{ Segment } & \multicolumn{2}{|c|}{ Epicenter of fault } & \multirow{2}{*}{$\begin{array}{c}\text { Depth } \\
(\mathrm{km})\end{array}$} & \multicolumn{2}{|c|}{ Fault Dimension } & \multirow{2}{*}{$\begin{array}{l}\text { Slip } \\
(\mathrm{m})\end{array}$} & \multirow{2}{*}{$\begin{array}{c}\text { Mo }(\mathrm{Nm}) \\
(\mathrm{mu}=10 \mathrm{GPa})\end{array}$} & \multirow{2}{*}{$\mathrm{Mw}$} \\
\hline & Lon (deg) & Lat(deg) & & $\mathrm{L}(\mathrm{km})$ & $\mathrm{W}(\mathrm{km})$ & & & \\
\hline Single & 107.989 & -9.405 & 10.0 & 200 & 80 & 3.95 & $6.33 E+20$ & 7.8 \\
\hline
\end{tabular}

Note: strike, dip, and slip angle is $289^{\circ}, 10^{\circ}$, and $95^{\circ}$ respectively

\section{Model Set-up}

To model 2006 Java tsunami-earthquake, we applied TUNAMI, which has been developed by DCRC Tohoku University Japan under the TIME project (Imamura 1997) and which uses the non linear shallow water equation (NSWE). In this paper, we will not provide the detail discussion on the numerical schemes as well as the governing equations included in this model since features, and its performances have been already extensively used in the tsunami scientific communities in past two decades. 
In order to numerically model the 2006 Java tsunami, the area and region considered are being treated as multi nested-grid sub-systems in which the outer domain always has a coarser spatial grid, and subsequently the inner domain is of finer resolution.

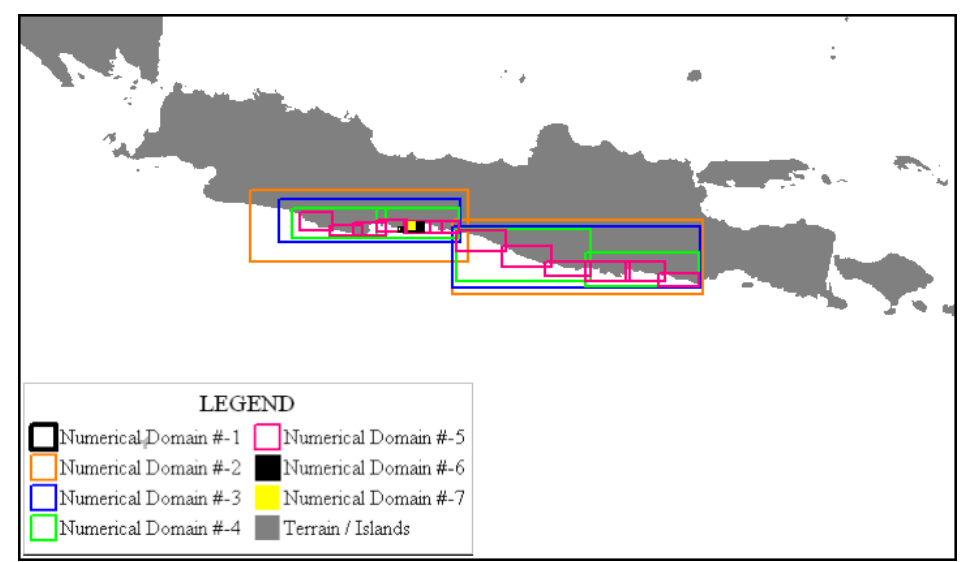

Figure 7. Numerical domain of 2006 java tsunami model
To save computational time, we proposed the numerical domain up to a level of 7 such that level $1^{\text {st }}(1), 2^{\text {nd }}(2), 3^{\text {rd }}(2)$, $4^{\text {th }}(4), 5^{\text {th }}(12), 6^{\text {th }}(2)$, and $7^{\text {th }}(2)$ represents the nest-grid level while the bracket corresponds to the domain number (see Figure 7).

Thus, the entire region has a total of 25 sub-systems, which are the spatial grid of $1^{\text {st }}$ to $7^{\text {th }}$ is set to be $\sim 1850 \mathrm{~m}, \sim 616 \mathrm{~m}, \sim 205$ $\mathrm{m}, \sim 68 \mathrm{~m}, \sim 23 \mathrm{~m}, \sim 7.6 \mathrm{~m}$, and $\sim 2.5 \mathrm{~m}$ respectively.

In order to ensure robust and stable numerical computations, the C.F.L. condition should be satisfied by giving the time step comparable small relative to the spatial grid; hence we set time step to $1 \mathrm{~s}, 1 \mathrm{~s}, 0.5 \mathrm{~s}, 0.3 \mathrm{~s}, 0.2 \mathrm{~s}, 0.1 \mathrm{~s}$, and $0.05 \mathrm{~s}$ for appropriate grid-spacing in reference. Furthermore, we estimate the total time simulation for 2006 Java's tsunami in between 5400 second (or 1.5 hours), assuming that from its source of origin, tsunami propagation and inundation reaches the coastline enabling $3-5$ subsequent tsunami wave crests to encounter the coast. We avoid longer time simulations in order to reduce the unexpected wave reflection due to boundary constraints in the smallest domain near to shore.

This model allows using the linear term or nonlinear term calculations depending on the consideration of the nested-grids system applied and its water depth, thus, achieving economic computing times. Here, we applied the linear model computation for domain $1^{\text {st }}$ to $4^{\text {th }}$, and the nonlinear model computation for the residual domains. In the nonlinear model computation, we employ uniformly distributed Manning's roughness value of $1 / 50$, assuming that in the run up area the terrain is of moderate roughness. However, in the particular area for validation purposes of maximum horizontal tsunami run-up heights, i.e. in Penyu Bay of Cilacap (tile 2 and tile 3 in Figure 5), we employed two different geographical models, namely a Digital Terrain Model (DTM) and a Digital Surface Model (DSM). This selection allows distinguishing between different land cover characteristics and land use types, i.e. vegetation, urban infrastructure, etc., which has been sampled and interpreted during field surveys.
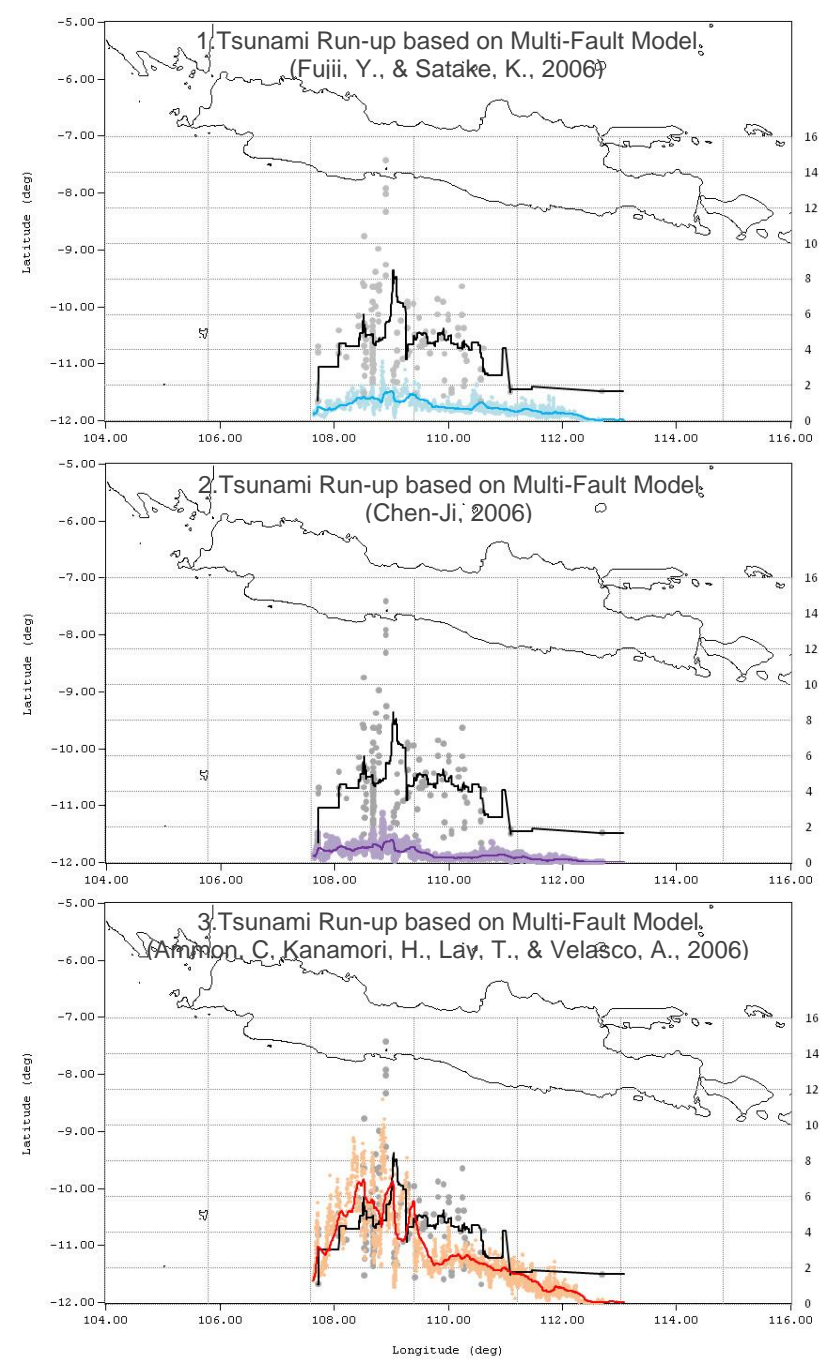

Figure 8. Model validation of run-up (source 1-3) 


\section{Model Validation}

The huge amounts of data have been collected in the aftermath of the 2006 Java tsunami, i.e. South Java coastline's tsunami run-up data, newly derived geo-data based on incorporating topographic and bathymetric data collected from field campaign and measurement in study area. By this means an extensive model allows validation for this specific event. In this context, we attempt to prove and validate the 2006 Java tsunami by means of a thorough numerical model based on a highly-resolved geo-data basis. The methodological approach considers the model validation of the tsunami run-up along South Java coastline, the tsunami marigram analysis recorded at the tide gauge of Cilacap, video captured by eye witness and the comparison of the selected inundation model results in study area with the maximum tsunami penetration locations on land.

Model validation of the tsunami run-up along South Java coastline has been conducted by comparing the field observation data and the model result. As pointed out previously, we applied preselected data of 110 points of 390 points of tsunami run-up along the $400 \mathrm{~km}$ coastline in South Java. These specific data have been collected within a distance of 20$180 \mathrm{~m}$ from the coastline. The main average beach slope in the area is $\sim 1 / 20$ to $1 / 50$.

For the tsunami model, we took the run-up data by collecting the maximum wave excursion in $5^{\text {th }}$ domain (grid-spacing is $\sim 23 \mathrm{~m}$ and already applied nonlinear term in the numerical model). These data have been collected in ranges of the water depth of $\sim 1-3 \mathrm{~m}$ with spatial acquisition $\sim 205 \mathrm{~m}$, thus each numerical subdomain contains tsunami run-up data ranging from 2910-3020 points dependent on the tsunami source.

Since the South-Java coastline is partially characterized by beach sections with fringing coral reef and, moreover, by complex bathymetric formations, model validation by comparing point to point data is not recommended; hence a statistical analysis approach is more applicable (Personal communication by Prof. Steven N. Ward). In order to adequately analyze the data, we used moving average analysis to filter underlying data sets.

Figure 8 and Figure 9 depict the model validation of the tsunami run up heights of the 2006 Java tsunami by means of comparing the selected field observation data and tsunami model result for six tsunami source models as indicated in table 1. The grey dots denote acquired field observation data (about 110 points) of in-situ tsunami run-up heights; the black trend-line represents the 205 moving average filtered data; light color dots shows modeled tsunami run-up heights (2010-3020 points) with its trend-line in light color line.

Both figures reveal remarkable variations of the underlying model results in contrast to the observed data from the field. Approaches using low rigidity of $10 \mathrm{GPa}$, i.e. tsunami source 3, 5, and 6, provide more reasonable agreement than those applying normal rigidity. These findings are reasonably justified since the initial sea surface heights are slightly larger leading to amplified tsunami run-up heights along the coastline. In addition, in terms of the tsunami run up distribution, those that use 


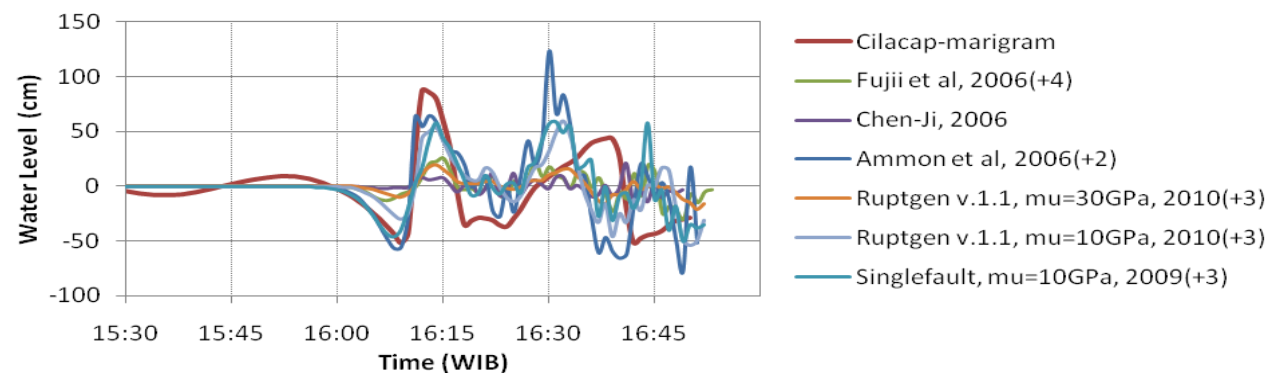

Figure 10. Marigram vs. water level at tide gauge of cilacap (109.019E, 7.753S)

multi-fault models are better than single-fault model, because the first model reflects the co-seismic slip distribution better than the latter model as shown in Figure 8 in the bottom panel (tsunami source 3). Run up heights of source model 5 also match field observations rather good. However, peak distribution slightly shifted to the West due to the usage of ambiguous estimated epicenter data given in the preliminary report just after the earthquake happened.

We also conducted model validation by analyzing tsunami marigram as it is freely available ${ }^{3}$. This particular data source was compared with the present tsunami model. The tsunami marigrams and corresponding water levels resulting from six source models are shown in Figure 10. In Penyu Bay of Cilacap, we have already employed the highly-resolved bathymetric data. However, we were still treating the time series' data by artificially delaying the signal by $2-4$ minutes in comparison to the original time basis ${ }^{4}$. This was necessary because there were still portion of nearshore as well as channel's zone where the bottom profile not covered in the surveys lead to tsunami time travel is slightly inaccurate and need to be adjusted.

Figure 10 also depicts the fact that all model results perform a leading depression wave and 2-3 subsequent significant waves during approximately 30 minutes. By evaluating the first wave, in terms of wave height, again the source model of 3,5 , and 6 show a comparable value to the tsunami marigram.
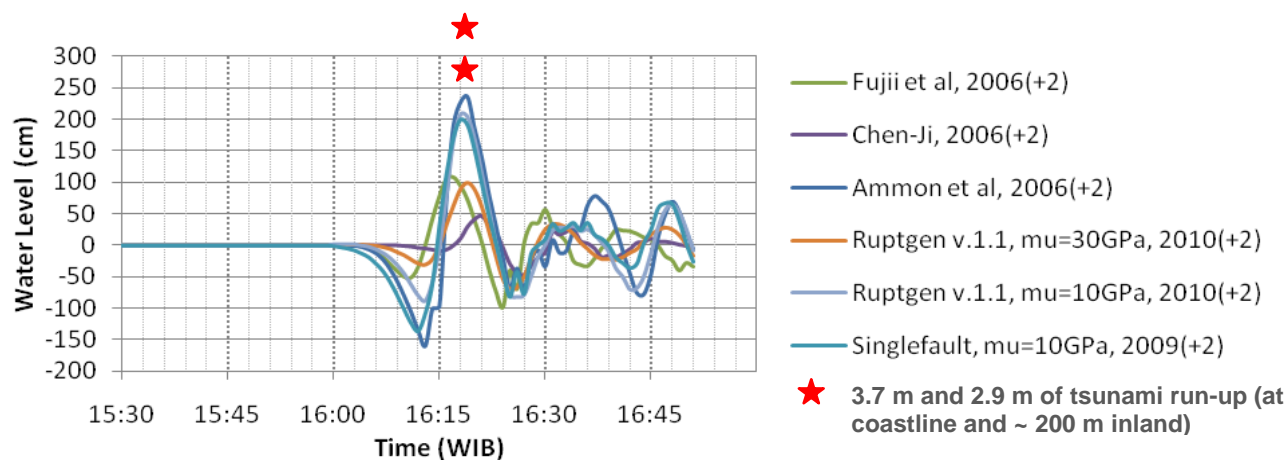

Figure 11. Marigram vs. water level at witness location in cilacap (109.089E, 7.691S)

A subsequent model validation takes benefit of the video sequence captured and published by Lavigne et al. (2007). This sequence visualizes the evolution of the tsunami taken by eye witnesses during the 2006 Java tsunami located near the ship basin of the steam power plant (PLTU). It clearly resembles the tsunami evolution when rushing towards the shore.

Figure 12 covers the tsunami in its approximate maximum state and in its preceding phase with each frame displayed in real time at the bottom of each subfigure. For model validation, we took the water level - time series' data in a virtual point located in ship basin approx. $300 \mathrm{~m}$ from the eye witness location, which has a water depth of about $5 \mathrm{~m}$. We estimated in such distance and depth, tsunami travels approx. 1- 2 minutes, and thus we shifted the data about 2 minutes, and the result is given in Figure 11 above. The tsunami evolution which its real time displayed in Figure 12 (A), (D), and $(\mathrm{E})$, and if they are plotted to the graph in Figure 11 give a suitable comparison; namely, when the wave attacks the shore, in its maximum state, and in its receding phase.

${ }^{3}$ http://www.vliz.be/vmdcdata/iode/blist. php?showmap=t.

4 As indicated by the values in the bracket in the figure's legend, 

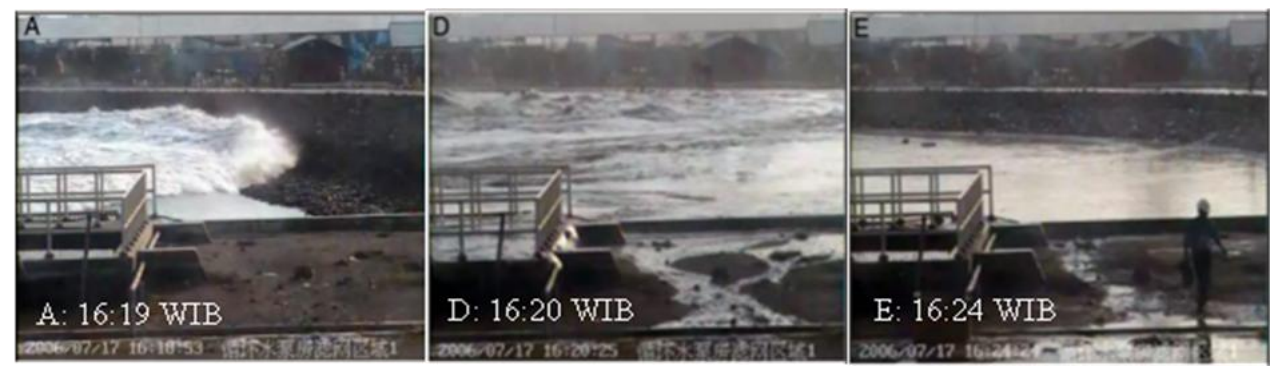

Figure 12. Sequence video captured corresponds to figure 11 (lavigne et al, 2007)

We also plot the nearest tsunami run-up data with its maximum run-up height of $3.7 \mathrm{~m}$ and $2.8 \mathrm{~m}$, approximately located on the coastline $200 \mathrm{~m}$ inland (denoted by red star in Figure 11). The results show comparable agreement; in particular those with source models 3, 5, and 6.

As mentioned in the previous sections in the study area of Cilacap, the DTM and DSM model as well as the ground level of additional measurement are available; this allows performing inundation model validation. This validation in three different locations given as tile boxes depicted in Figure 5. The tile 1 (brown) is Permisan - the prison area adjacent $20 \mathrm{~km}$ South-West Cilacap city. The tile 2 (red) is located surrounding river mouth of Serayu - the place that the 2006 Java's tsunami penetration went further inland, and the most victims happened. And the tile 3 (blue) is located in the eastern part of Cilacap.

As for inundation model validation, due to time constraint, we selected one source model giving the best fit compared to the field observation data and tsunami marigram analysis. In this order source model 3 is taken. We compare the inundation model result using source model 3 and overlay results with the maximum run up field observation's points. In tile 1, we collected maximum tsunami run-up in 29 of 36 points, which were all located in the steep-slope hilly area. In tile 2 and tile 3, we estimated the maximum tsunami penetration in 23 points on the basis of testimonies of the survivals' interview mentioned in previous sections.

Figure 13 shows the inundation model validation of 2006 Java tsunami, comparing the

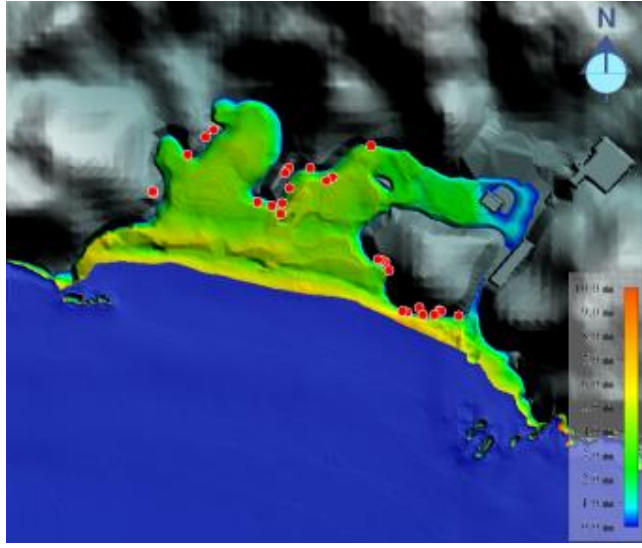

Figure 13. Tile 1, Inundation model vs. field obs. (red dot) inundation model result in $7^{\text {th }}$ domain in tile 1 (cf. Figure 5) with 29 points of maximum tsunami runup (excluding seven flow-depth points data) conducted by Fritz et al and Lavigne et al. The inundation went further inland except in the eastern part where a hill blocks the tsunami. It reached and climbed the hills surrounding Permisan and a little portion inundated the surrounding prison area, which was also confirmed by local people who have been interviewed during the ground survey.

Figure 13 clearly shows that the tsunami run-up points of the field observation (indicated by red dot) are more or less reaching the peaks of maximum run up heights resulting from the model indicating the horizontal model validation has a good result. In contrast, the comparison of vertical tsunami run-up heights for both model result and field observation has significant discrepancies.

By evaluating both data, the tsunami run-up resulting from the model gave only an average fit of $53 \%-57 \%$ of the field observation data, which are $17 \%-45 \%$ of the data points in the dry area. Such varying percentage seems due to the source of

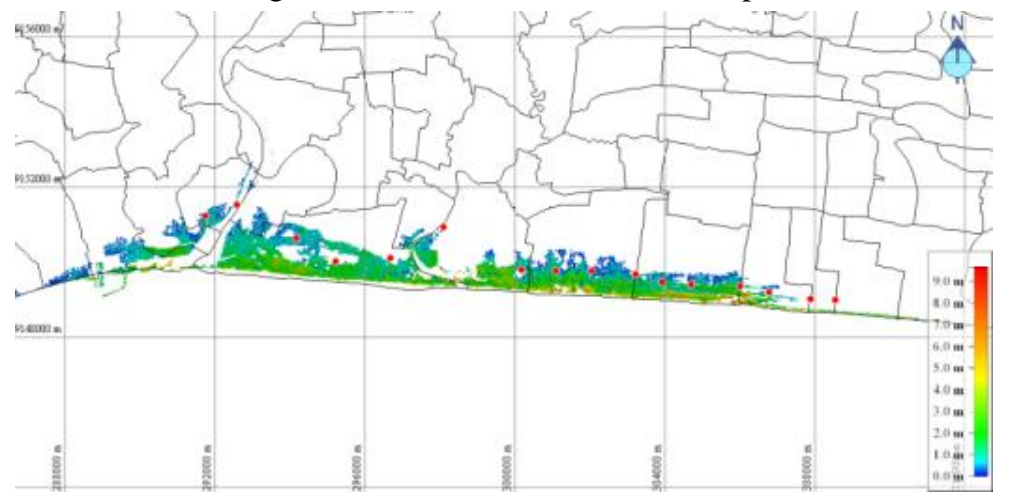

Figure 14. Tile 2, Inundation model vs. field obs. (red dot) 
terrain model data during geometric data assimilation. This resembles the fact that not the full area in the numerical domain was covered by field measurement, especially those located on a very steepslope and in inaccessible densely-covered areas (trees and bushes). In order to fill such a blank data, the rough resolution from the digital surface model of SRTM 30 and SRTM 90 were used leading to less accurately ground level resolution and, thus, less spatial accuracy.

For other model validation purposes, we also compared the inundation model results with the estimation horizontal maximum run-up in two distinct places; located in the Penyu Bay of Cilacap as shown in tile 2 and tile 3 in Figure 5. The model validation in tile 2 as depicted in Figure 14 presents 14 of 16 points (indicated by red dot) with fair approximation compared with the estimation of 2006 Java's tsunami penetration inland based on interviewed local people. Also, fair results could be obtained by comparing the 7 points of the estimation tsunami penetration in tile 3 of Figure 5 to the inundation model, as shown in Figure 15.

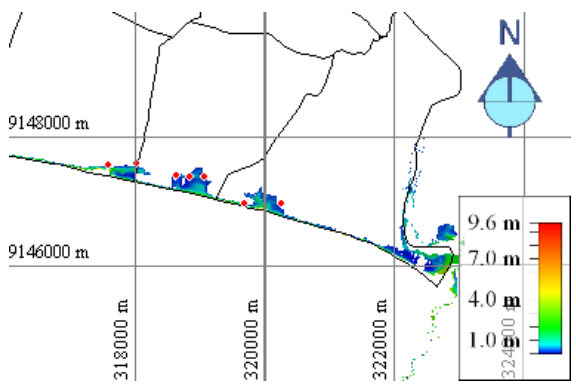

Figure 15. Tile 3, Inundation model vs. field obs. (red dot)

The three model validations; two model validations using six source models and one model validation using one selected source model, have been conducted above and give qualitative and quantitative model performances. In regard to model validation of the tsunami run up distribution as well as tsunami marigram analysis, it is clearly shown that the 2006 Java's tsunami can be mimicked by model that imposed low rigidity material at excitation zone, so-called accretionary prism as represented by source model 3,5, and 6, and in particular it is well represented by multi-faults model 3. In addition, further examinations of model performance by horizontal inundation model validation in three places (in tile 1-3) using selected source model 3 also give reasonable agreement.

The conclusion can be drawn that the 2006 Java tsunami can be modeled with the comparable results of tsunami run-up along the coastline and their inundation to field observation data. It is most likely that the low rigidity in accretionary prism gave a significant role to the event and its multi-faults type of the source model give the best fit among others.

\section{FUTURE TSUNAMI MODEL}

\section{Model Scenario}

The 2006 Java tsunami assessment by extensively tsunami model validations as demonstrated in previous section suggests that tsunami with their epicenters being located in accretionary prism could give bigger run-ups. In addition, multi-faults models performed better in terms of tsunami run-up distribution along the coastline. However, to perform the latter is only possible for post-tsunami analysis, which the necessary data are available to estimate the slip distribution derived from the inversion model as produced from either teleseismic body waveform or tide gauges surroundings of the epicenter's region. Hence, in this section we conduct the tsunami model by involving only the estimated low rigidity accretionary prism. For the source model's type, a single fault is imposed, assuming that the coastline of Cilacap which is in the focus of the study is relatively short, i.e. approximately $50 \mathrm{~km}$.

To model reasonable future tsunami scenarios of Cilacap, we propose a limited multi-scenario hypothetic tsunami model, which focuses on the plausible maximum of the certain magnitude given in the Java's subduction zone with a tsunami exerts gives maximum impact on Cilacap region. To accommodate this, we made several assumptions as the followings:

- Scenarios of the hypothetic model are the expected events that give plausible maximum impact to the study area.

- The epicenters are close to the Java trench $(<70 \mathrm{~km})$ and their hypocenters are shallow (shallow dip, $<25 \mathrm{~km}$ ), thus the ruptures can be assumed to occur in the accretionary prism and its tsunami excitation is influenced by low rigidity material (to be assumed of $10 \mathrm{GPa}$ ).

- To obtain the maximum impact, the epicenters' coordinates are located in the area in a way that the major section of the virtual rectangular rupture faces / is normal to study area. 
- The scenario magnitudes are estimated based on tsunami historical data that happened in the Java's subduction zone, namely Mw7.8 to Mw 8.2 with interval 0.2.

- Parameter sources, i.e. angle parameters based on historical data (1994 \& 2006 events); strike $\left(278^{\circ}-297^{\circ}\right)$, dip $\left(7^{\circ}-11^{\circ}\right)$, slip $\left(89^{\circ}-102^{\circ}\right)$ and focal depth $(<25 \mathrm{~km})$.

- Rupture dimensions are proposed by considering empirical studies conducted by Wells \& Coppersmith (1994), Papazachos et al. (2004), Okal (1988), and 2006 Java tsunami event. The single fault type of source model is considered.

Following such assumptions above, we then proposed 16 credible locations of epicenter off the coast of the South Cilacap region of which 12 are oriented in terms of strike direction normal to study area, two epicenters are similar to the 2006 and 1994 Java tsunami events, respectively, and residual sources depict two epicenters placed between a set of 12 epicenters above and 1994 Java's tsunami (see Figure 16).

\begin{tabular}{|c|c|c|c|c|c|c|}
\hline \multirow{2}{*}{ 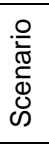 } & \multicolumn{2}{|c|}{ Epicenter } & \multirow{2}{*}{ 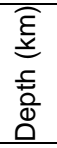 } & \multicolumn{3}{|c|}{ Angle } \\
\hline & Lon (deg) & Lat(deg) & & $\begin{array}{l}\text { 亲 } \\
\text { 心 }\end{array}$ & $\stackrel{ }{\circ}$ & 음 \\
\hline 1 & 108.0080 & -9.7773 & 5 & $289^{\circ}$ & $10^{\circ}$ & $95^{\circ}$ \\
\hline 2 & 108.4042 & -9.9079 & 5 & $289^{\circ}$ & $10^{\circ}$ & $95^{\circ}$ \\
\hline 3 & 108.7991 & -10.0380 & 5 & $289^{\circ}$ & $10^{\circ}$ & $95^{\circ}$ \\
\hline 4 & 108.8759 & -9.8198 & 10 & $289^{\circ}$ & $10^{\circ}$ & $95^{\circ}$ \\
\hline 5 & 108.4843 & -9.6805 & 10 & $289^{\circ}$ & $10^{\circ}$ & $95^{\circ}$ \\
\hline 6 & 108.0923 & -9.5494 & 10 & $289^{\circ}$ & $10^{\circ}$ & $95^{\circ}$ \\
\hline 7 & 108.1687 & -9.3417 & 15 & $289^{\circ}$ & $12^{\circ}$ & $95^{\circ}$ \\
\hline 8 & 108.5578 & -9.4720 & 15 & $289^{\circ}$ & $12^{\circ}$ & $95^{\circ}$ \\
\hline 9 & 108.9554 & -9.6059 & 15 & $289^{\circ}$ & $12^{\circ}$ & $95^{\circ}$ \\
\hline 10 & 107.3200 & -9.2220 & 10 & $289^{\circ}$ & $10^{\circ}$ & $95^{\circ}$ \\
\hline 11 & 108.6800 & -9.2100 & 25 & $289^{\circ}$ & $15^{\circ}$ & $95^{\circ}$ \\
\hline 12 & 110.0032 & -10.0197 & 10 & $280^{\circ}$ & $10^{\circ}$ & $95^{\circ}$ \\
\hline 13 & 111.1466 & -10.2193 & 10 & $280^{\circ}$ & $10^{\circ}$ & $95^{\circ}$ \\
\hline 14 & 112.8350 & -10.4770 & 10 & $280^{\circ}$ & $10^{\circ}$ & $95^{\circ}$ \\
\hline 15 & 109.0468 & -9.3349 & 25 & $289^{\circ}$ & $15^{\circ}$ & $95^{\circ}$ \\
\hline 16 & 112.8350 & -10.4770 & 10 & $289^{\circ}$ & $15^{\circ}$ & $95^{\circ}$ \\
\hline
\end{tabular}

Table 5 shows the underlying source parameters, consisting of epicenter's geographic coordinates, focal depths, and angle parameters for 16 hypothetic models. The epicenters follow the dots and stars as depicted in Figure 16, hypocenters are assumed in accretionary prism which its depth $<25 \mathrm{~km}$; closer to Java coastline is deeper. Angle parameters are based on tsunami historical data records, i.e. for strike angles in the West zone of $\sim 110^{\circ} \mathrm{E}$, the parameter is set to be $289^{\circ}$, while it is set to be $280^{\circ}$ in the East zone, which both are more and less parallel to the Java trench. The dip angles value are generally set to follow the depth, further to the North is higher, while slip angles are set to be the constant value of $95^{\circ}$.

Regarding the scenario magnitude, we refer to the tsunami historical data that occurred in Sunda trench in 2006 (USGS 2006), in 1994, Tsuji et al. (1995), and in 1977, Gusman et al. (2009) which its magnitude ranging from $\mathrm{Mw} 7.6$ to $\mathrm{Mw}$ 8.2. For the hypothetic model, we select $\mathrm{Mw}$ 7.8, $\mathrm{Mw}$ 8.0, and $\mathrm{Mw} 8.2$ as shown in Table 6. Furthermore, rupture dimensions of the hypothetic model are calculated by using previous empirical studies by Okal (1988) in column 1, Wells \& Coppersmith (1994) in column 2, and Papazachos et al. (2004) in column 3, while in column 4 it is proposed by authors for in present study, (see Table 6).

The calculated slips in column 1 and 3 based on the rigidity which was automatically assumed to be a constant of $50 \mathrm{GPa}$. In Column 2 and 4, the slips were calculated using low rigidity of $10 \mathrm{GPa}$. The rupture length which we proposed in column 4 which is almost similar to column 2 , but the rupture width is doubled by considering the last event of 2006 Java's tsunami and the ratio of $\mathrm{L} / \mathrm{W} \sim 2$ 3 as empirical studies by Geller (1976) and Okal (1988).

\begin{tabular}{|c|c|c|c|c|c|c|c|c|c|c|c|c|c|}
\hline \multicolumn{10}{|c|}{ Table 6. Rupture dimension for hypothetic model } \\
\hline Hypo. & \multicolumn{10}{|c|}{ Rupture Dimension-1) } & \multicolumn{2}{c|}{ Rupture Dimension-2) } & \multicolumn{2}{c|}{ Rupture Dimension-3) } & \multicolumn{2}{c|}{ Rupture Dimension-4) } \\
\hline $\begin{array}{c}\text { L } \\
(\mathrm{Mw})\end{array}$ & $\begin{array}{c}\mathrm{W} \\
(\mathrm{Km})\end{array}$ & $\begin{array}{c}\text { Slip } \\
(\mathrm{Km})\end{array}$ & $\begin{array}{c}\mathrm{L}) \\
(\mathrm{Km})\end{array}$ & $\begin{array}{c}\mathrm{W} \\
(\mathrm{Km})\end{array}$ & $\begin{array}{c}\text { Slip } \\
(\mathrm{m})\end{array}$ & $\begin{array}{c}\mathrm{L} \\
(\mathrm{Km})\end{array}$ & $\begin{array}{c}\mathrm{W} \\
(\mathrm{Km})\end{array}$ & $\begin{array}{c}\text { Slip } \\
(\mathrm{m})\end{array}$ & $\begin{array}{c}\mathrm{L} \\
(\mathrm{Km})\end{array}$ & $\begin{array}{c}\mathrm{W} \\
(\mathrm{Km})\end{array}$ & $\begin{array}{c}\text { Slip } \\
(\mathrm{m})\end{array}$ \\
\hline 7.8 & 95.5 & 47.7 & 2.77 & 197.4 & 45.9 & 6.96 & 125.9 & 61.4 & 1.63 & 200.0 & 80.0 & 3.95 \\
\hline 8.0 & 120.2 & 60.1 & 3.48 & 268.9 & 56.4 & 8.31 & 162.2 & 70.8 & 2.19 & 275.0 & 110.0 & 4.15 \\
\hline 8.2 & 151.4 & 75.7 & 4.38 & 366.2 & 69.2 & 9.91 & 208.9 & 81.7 & 2.94 & 375.0 & 150.0 & 4.46 \\
\hline
\end{tabular}

\section{Model Set-up}

The numerical domain consists of 5 subdomains. The largest domain $1^{\text {st }}$ occupies Java Island and its surroundings including the subduction zone, the smallest domain $5^{\text {th }}$ includes Cilacap district as 
shown by nested boxes in Figure 16. The spatial grids and their time step are set up analogue to the tsunami model for 2006 Java tsunami as presented in previous section, as well as its Manning roughness, which is imposed only in the smallest numerical domain. The total simulation time is set to be $5400 \mathrm{~s}$ (or 1.5 hours), assuming that during this time, the tsunami have propagated, reached the coastline, and then run-up onto Cilacap terrain with subsequently 3-4 tsunami waves.

We conducted the model in a way that the numbers of the running model are following the combination of the parameters, namely three scenarios (Mw 7.8, 8.0, 8.2), 16 epicenters, and three condition of mitigation measures (without mitigation measures, with greenbelt, and with sand dunes) which will be detail explained in next section. This leads to 144 runs of the numerical model.

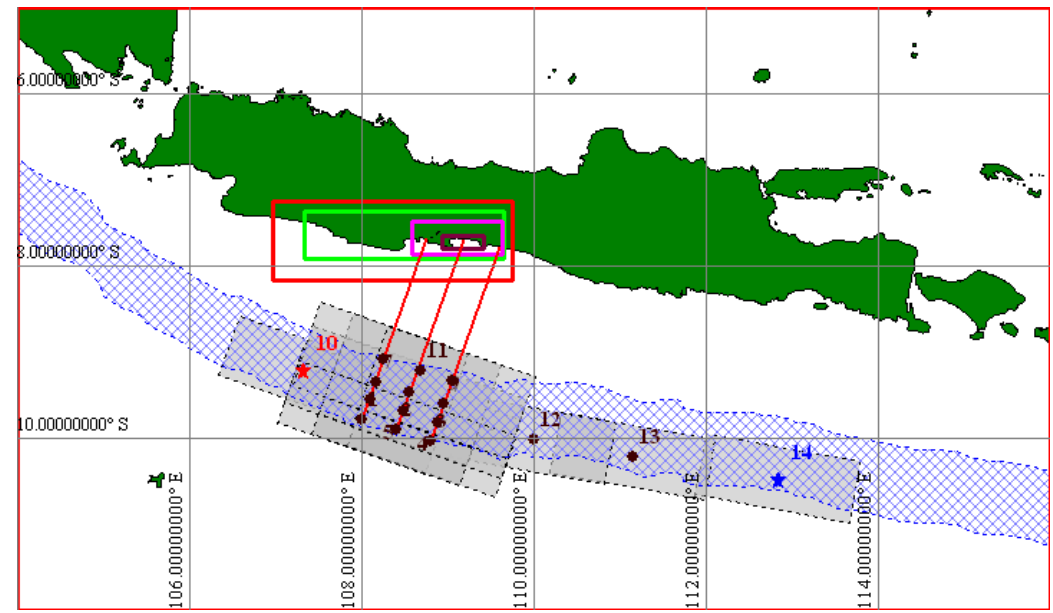

Figure 16. Numerical domain \& epicenters of cilacap hypothetic model

The geometric data used in this simulation is similar to the 2006 Java tsunami model, namely GEBCO 2008 for domain $1^{\text {st }}$ to $4^{\text {th }}$ and the assimilating data from various measurements (bathymetric surveys) and sources for domain $5^{\text {th }}$. In particular areas, the DTM was used instead of the DSM data, as the former has the advantage that vegetations and infrastructures have been removed which leads to larger inundation and gives higher safety. Also, an astronomical tide was imposed at the highest water level (HWL) as well as an additional estimated wave setup during burst, which both together are assumed to be $1.5 \mathrm{~m}$.

In this simulation, technical mitigation measures using greenbelt to reduce tsunami were examined, hence, in order to include its hydraulic roughness, the Morison equation has been used, $C_{D}$ (drag coefficient) and $C_{M}$ (inertia coefficient) being approximated based on the laboratory study by Harada \& Imamura (2000). As for those using sand dunes, its profiles are simply to be included and added on terrain data.

\section{Mitigation Measures}

For mitigation purposes, the artificial sand-dunes and 'Waru' trees (Hibiscus Tiliaceus) as a coastal greenbelt to protect against tsunami were examined. Figure 17 shows the map of Cilacap district with the proposed layout of the mitigation measures (red solid line) located in the low-level beach. As a first step, the natural beach (without mitigation measures) was examined, and further on the mitigation measure of $100 \mathrm{~m}$ width of the sand-dune with its height $7.5 \mathrm{~m}$ was included in the design.

In the last attempt, a width of $200 \mathrm{~m}$ of 'Waru' trees with a density of 16 trees $/ 100 \mathrm{~m}^{2}$ was applied

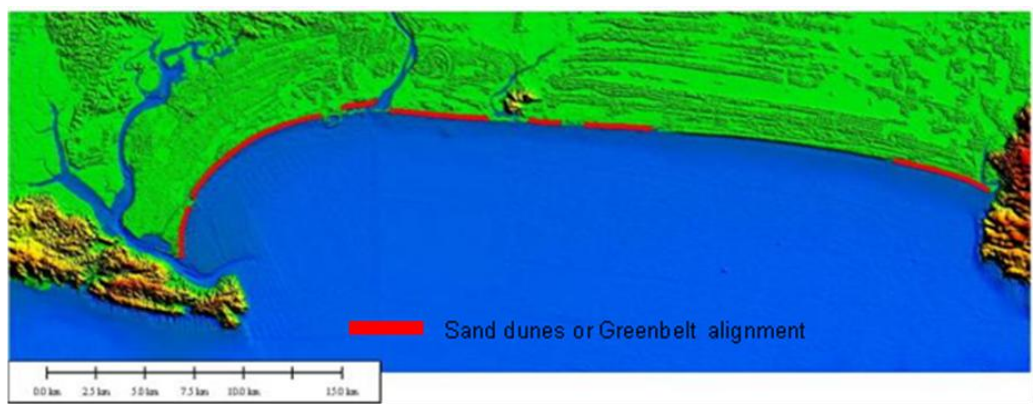

Figure 17. Lay-out of mitigation measures as a greenbelt coastal protection. The other tree parameters are a trunk height of $3.5 \mathrm{~m}$, a trunk diameter of $0.35 \mathrm{~m}, \quad \mathrm{a}$ branch height of $1.5 \mathrm{~m}$, a branch diameter of $2.5 \mathrm{~m}$ and a branch density of 0.20 , as the detail sketch in Figure 18. 


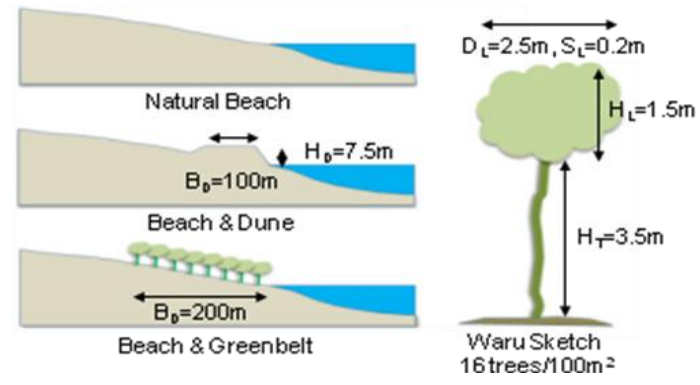

Figure 18. Sketch of sand-dunes \& greenbelt

\section{Inundation Model}

As mentioned in previous section, the numbers or runs of the numerical model is 144 , which consists of a combination classified by three magnitudes, three mitigation measures types and 16 epicenters. An inundation map was set up on the basis of 16 epicenters by taking the envelope of each

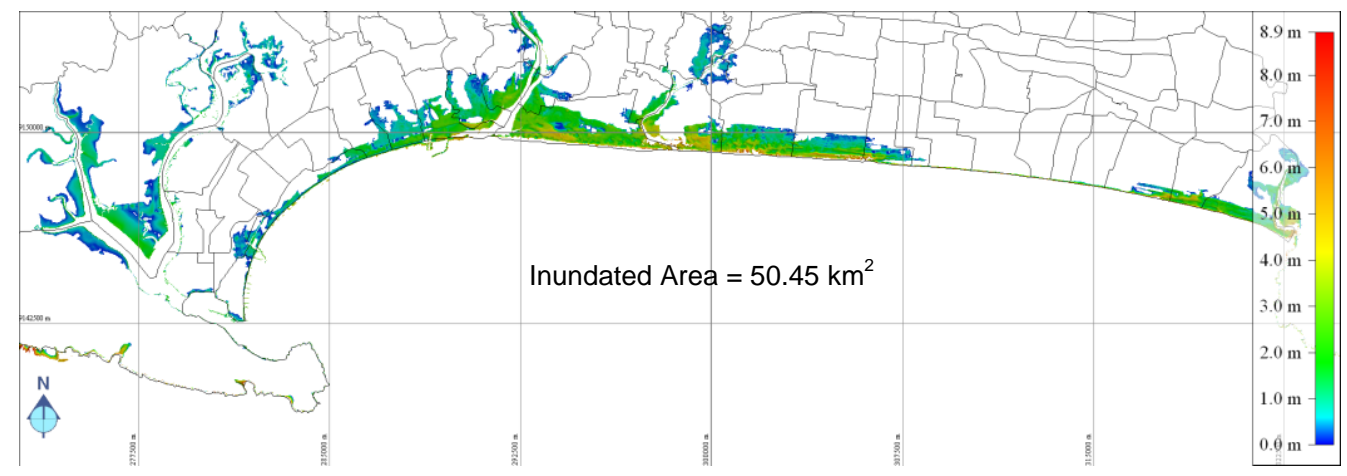

Figure 19. Hypothetic tsunami inundation model (Mw 8.2 - without mitigation measures)

maximum inundation of each epicenter, yielding nine inundation maps. Figure 19 shows one of the exemplary model results of the hypothetic tsunami model under the condition of an Earthquake magnitude of $\mathrm{Mw}$ 8.2. Without mitigation measures, the inundated area mounts to $50.45 \mathrm{~km}^{2}$.

Based on the hypothetic model result, it can be concluded that in general the tsunami inundation is concentrated in three regions; in the upstream river of Donan -West region, in the river mouth of Serayu and its surroundings (up to $\sim 15 \mathrm{~km}$ further East, incl. river of Bengawan) - Center part, and in the river of Jetis - East region. The farthest tsunami penetration and the most inundated area is expected in the center of Cilacap, since this area is low-land tributaries zone and exposed to the open sea. In addition, the headland of Nusakambangan Island (West region) seems an effective barrier to protect Cilacap city against tsunami.

In Figure 20 shows a bar chart of the entire inundated area classified by magnitudes and mitigation measures. Based on this chart, it can be concluded that in general, the mitigation measures by sanddunes are more effective than using a greenbelt, with an average percentage effectiveness of $26.7 \%$ for sand-dunes and $6.9 \%$ for greenbelts. Furthermore, it was observed that the higher the magnitude, the lower was the average percentage of the effectiveness; as for Mw 7.8, the highest average percentage effectiveness is $29.5 \%$ and $7.6 \%$ for sand-dunes and greenbelt respectively.

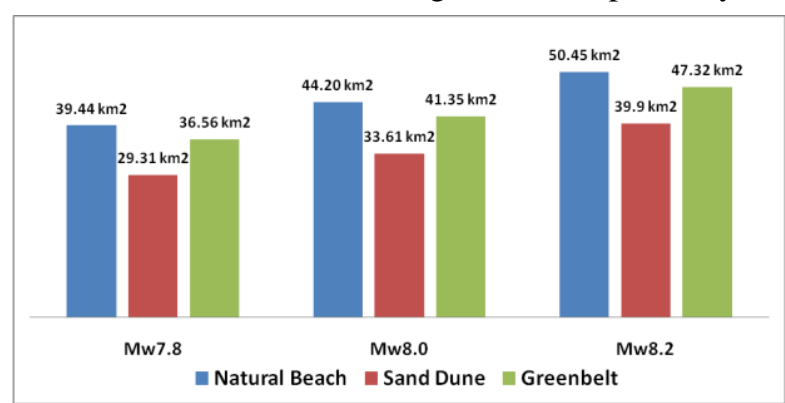

Figure 20. Tsunami Inundation Area 


\section{RESUMES \& RECOMMENDATIONS}

South Java is prone tsunami area, and Cilacap district is vulnerable to tsunami because of the facts that it has dense population, a lot of vital infrastructures, and a flat topographic terrain. Thus, for future tsunami mitigation purposes, its assessment of this area is highly demanded.

An extensive tsunami assessment has been conducted by the extent of the 2006 Java tsunami run up data stretched along more than $400 \mathrm{~km}$ of South Java coastline and the new highly-resolved bathymetric and topographic measurement data in the study area of Cilacap. The data includes about 390 points of field observation of tsunami run up, more than 1200 points of total station equipped ground level topographic campaign, 23 points of estimated run-up by local's interviews and about 70 $\mathrm{km}^{2}$ of single-multi beam echo-sounder equipped survey. Furthermore, the up-to-date secondary data, such as DTM/DSM Intermap data, GEBCO 2008, and bathymetric chart of Penyu Bay of Cilacap was integrated in the data base.

A 2D non linear shallow water equation model was used for this study, which was validated using several available and proposed source models. The model validation for the 2006 Java tsunami showed fair-good results in terms of the tsunami run up distribution, tsunami marigram analysis, and the inundation in the study area. In terms of the source model, it is very likely that the tsunami excitation located in accretionary prism, which strongly influenced by low rigidity material leads to higher seafloor displacement and gives higher tsunami run up. In addition, its distribution along the coastline is also influenced by source model type; single-fault and multi-fault that represented the co-seismic slip distribution.

To the future tsunami hazard in the study area, the limited multi scenario of plausible maximum inundation has been proposed and an envelope inundation classified by a certain magnitude and tentatively mitigation measures was attained. According to the model result, the tsunami inundation is expected to be concentrated in three regions, where the farthest tsunami penetration and most severe inundated area is in the center of Cilacap; in the river mouth of Serayu and its surroundings. In addition, the headland of Nusakambangan Island seems an effective barrier protect Cilacap city against tsunami.

The proposed mitigation measures and their effectiveness have also been examined, with the general outcome that sand-dunes are approximately four times more effective than greenbelts. However, for mitigation purposes these efforts are still far insufficient, and more effective mitigation attempts of future tsunami disasters in the study area are highly demanded. In general, it is strongly recommended to integrate approaches by means of vertical-horizontal evacuation to evacuate peoples who reside in the affected area. In the most inundated area, in the center of Cilacap, the coastal protections for reducing tsunami impact, which threatens vital infrastructures (such as PLTU, Fishery Port, etc.), are also highly required.

\section{ACKNOWLEDGMENTS}

We would like to acknowledge GITEWS project who support all the data. We thank Coordinating Agency for Surveys and Mapping of Indonesia (BAKOSURTAL) for providing the bathymetric chart and tsunami marigram data.

\section{REFERENCES}

A.Y.Babeyko, 2007. Rupture Generator v.1.1., Potsdam, Germany.

Abidin, Z.H. \& Kato, T., 2007. Why Many Victims: Lessons from the July 2006 South Java Tsunami Earthquake. Advances in Geoscences, 13, 249-263.

Ammon, C.J. et al., 2006. The 17 July 2006 Java Tsunami Earthquake. Geophysical Research Letters, 33(L24308), 1-5.

CEA-France, 2007. South of Java Earthquake and Tsunami, July 17, 2006, Available at: http://wwwdase.cea.fr/actu/dossiers_scientifiques/2006-07-17/index_en.html\#Tsunami.

DCRC - Univ. Tohoku - Japan, 2007. Modeling a tsunami generated by the July 17, 2006 Earthquake , South of Java, Available at: http://www.tsunami.civil.tohoku.ac.jp/hokusai2/disaster/06_Java/July17_Java.html.

DPPK-Cilacap, 2007. Potensi Unggulan Daerah dan Peluang Investasi Cilacap (Investment 
Opportunities), Dinas Perindustrian Perdagangan dan Koperasi, Kab.CIlacap.

Fritz, H.M. et al., 2007. Extreme Runup from the 17 July 2006 Java Tsunami. Geophysical Research Letters, 34(L12602), 1-5.

Fujii, Y. \& Satake, K., 2006. Source of the July 2006 Java Tsunami Estimated from Tide Gauge Records. Geophysical Research Letters, 33(L23417), 1-5.

Geller, R.J., 1976. Scaling relations for earthquake source parameters and magnitudes. Bulletin of the Seismological Society of America, 66(5), 1501-1523.

Gusman, A.R. et al., 2009. Analysis of the Tsunami generated by the great 1977 Sumba earthquake that occurred in Indonesia. Bulletin of the Seismological Society of America, 99(4), 21692179.

Hanifa, R.N. et al., 2007. Numerical Modeling of The 2006 Java Tsunami Earthquake. Advances in Geoscences, 13, 231-248.

Hanks, T.C. \& Kanamori, H., 1979. A Moment Magnitude Scale. Journal of Geophysical Research, 84(B5), 2348-2350.

Harada, K. \& Imamura, F., 2000. Experimental Study on the Resistence by Mangroves under the Unsteady Flow. In Prooceding of the 1st Congress of APACEst, pp.975-984.

Imamura, F., 1997. Numerical Method of Tsunami Simulation with the Leap-Frog Scheme, IOCUNESCO.

Intermap Federal Services, I., 2007. Digital Terrain Model Cilacap, DLR Germany.

Italy, T.U., 2007. The Java Tsunami, July 17 2006: Preliminary Numerical Simulations, Available at: http://labtinti4.df.unibo.it/tsunami/site/simulation\$_\$java.php\#case4.

ITDB/WLD, 2007. Integrated Tsunami Database for the World Ocean, ver.6.52 of Dec.31 2007, Tsunami Lab. ICMMG SD RAS, Novosibirsk, Russia,

Ji, C., 2007. M7.7, Indonesia Earthquake of 17 July 2006, Available at: http://neic.usgs.gov/neis/eq_depot/2006/eq_060717_qgaf/neic_qgaf_ff.html.

Kongko, W. \& Leschka, S., 2009. Bathymetry measurements in Indonesia, Part 2: Cilacap, DHIWASY GmbH Syke Germany.

Kongko, W. et al., 2006. Rapid Survey on Java Tsunami 17 July 2006, http://ioc3.unesco.org/itic/files/tsunami-java170706_e.pdf.

Kopp, H. \& Kukowski, N., 2003. Backstop Geometry and Accretionary Mechanics of the Sunda Margin. Tectonis, 22(6), 11-1 - 11-16.

Lavigne, F. et al., 2007. Field Observation of the 17 July 2006 Tsunami in Java. Natural Hazards and Earth Systems Sciences, 7, 177-183.

Mansinha, L. \& Smylie, D.E., 1971. The Displacement Fields of Inclined Faults. Bulletin of the Seismological Society of America, 61(5), 1433-1440.

Okada, Y., 1985. Surface Deformation due to Shear and Tensile Faults in a Half-space. Bulletin of the Seismological Society of America, 75(4), 1135-1154.

Okal, E.A., 1988. Seismic Parameters Controlling Far-field Tsunami Amplitudes: A Review. Natural Hazards, 1, 67-96.

Papazachos, B.C. et al., 2004. Global relations between seismic fault parameters and moment magnitude of earthquakes. Tenth Congr Hellenic Geol Soc, XXXVI, 539-540.

Takahashi, S. et al., 2008. Indonesia-Japan Joint Survey on 2006 Java Earthquake. In ICCE.

Tsuji, Y. et al., 1995. Field Survey of the East Java Earthquake and Tsunami of June 3, 1994. Pageoph, 144(3/4), 839-854.

USGS, 2006. Magnitude 7.7 - SOUTH OF JAVA, INDONESIA-USGS. Available at: http://earthquake.usgs.gov/earthquakes/eqinthenews/2006/usqgaf/\#summary.

USGS, 2010. Source Parameters of Earthquake Mw 6.5 above at Java Subduction Zone. Available at: http://earthquake.usgs.gov/earthquakes/eqarchives/sopar/.

Wells, D.L. \& Coppersmith, K.J., 1994. New empirical relationships among magnitude, rupture length, rupture width, rupture area, and surface displacement. Bulletin - Seismological Society of America, 84(4), 974-1002. 